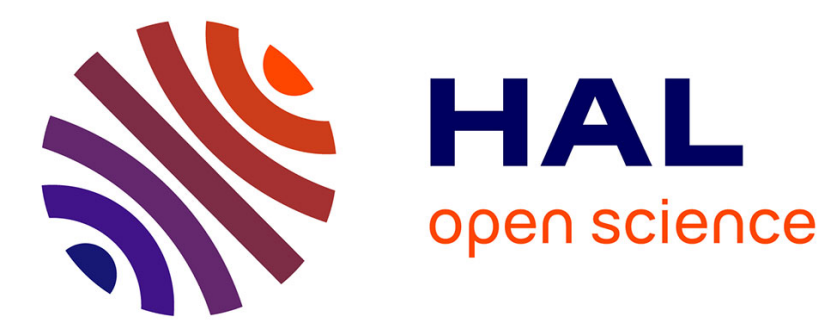

\title{
Understanding the Role of Collective Imaginary in the Dynamics of Expectations: The Space Industry Case Study
}

Benjamin Cabanes, Blanche Segrestin, Benoit Weil, Pascal Le Masson

\section{- To cite this version:}

Benjamin Cabanes, Blanche Segrestin, Benoit Weil, Pascal Le Masson. Understanding the Role of Collective Imaginary in the Dynamics of Expectations: The Space Industry Case Study. 21st International Product Development Management Conference, Jun 2014, Limerick, Ireland. hal-01010134

HAL Id: hal-01010134

https://hal-mines-paristech.archives-ouvertes.fr/hal-01010134

Submitted on 19 Jun 2014

HAL is a multi-disciplinary open access archive for the deposit and dissemination of scientific research documents, whether they are published or not. The documents may come from teaching and research institutions in France or abroad, or from public or private research centers.
L'archive ouverte pluridisciplinaire HAL, est destinée au dépôt et à la diffusion de documents scientifiques de niveau recherche, publiés ou non, émanant des établissements d'enseignement et de recherche français ou étrangers, des laboratoires publics ou privés. 


\title{
Understanding the Role of Collective Imaginary in the Dynamics of Expectations: The Space Industry Case Study
}

\author{
Benjamin Cabanes $^{1 *}$, Blanche Segrestin ${ }^{1}$, Benoit Weil ${ }^{1}$, Pascal Le Masson ${ }^{1}$ \\ ${ }^{1}$ MINES ParisTech, PSL - Research University, CGS - Center for Management Science, 60 Bvd \\ Saint Michel, 75272 Paris Cedex 06, France. \\ ${ }^{*}$ Corresponding author. \\ Postal address: MINES ParisTech, 60 boulevard Saint-Michel, F-75272 Paris Cedex 06, France \\ E-mail: benjamin.cabanes@mines-paristech.fr
}

\begin{abstract}
The main objective of this study attempts to contribute to a growing body of research in the understanding of innovation and technological development. When addressing radical changes in technology and innovation, ideas derived from expectations and promises have become key issues in transforming a vision into reality. Thus, our paper aims to investigate the dynamics of expectations and its relationship to the collective imaginary when applied to the space industry. The space industry is one of the most exemplary cases to study the dynamics of social expectations (i.e. space observation, space exploration, the conquest of space, and etc.) and it has clearly been considered as a strong stimulus for design efforts. In order to illustrate the processes involved with fulfilling the design of new visions and innovative promises, we use the most recent models of design reasoning (C-K theory) to support our hypothesis.
\end{abstract}

\section{Introduction}

The current literature highlights a phenomenon of expectations, which is recognized to play a critical role in radical systems within innovation (Smith et al., 2010). The case studies proposed by Van Lente (1993) and Van Lente and Rip (1998) have contributed to illustrate the dynamic of expectation in technological development. Moreover, Geels and Raven's Biogas case (2006) and Robinson and Propp's study, of lab-on-a-chip technology (2008) propose a myriad method of assessment to analyze the robustness and pertinence of expectations. Then, as underlined by Borup et al. (2006), future-oriented abstractions are among the most important objects of enquiry for scholars and analysts of innovation. Expectations can guide activities, provide structure, add to legitimate claims, attract interest and foster investment. Yet, so far, they are still very few attempts to follow in a systematic way, how expectations emerge, as to how their imaginaries develop and how they can be renewed. We define a collective imaginary as a set of propositions having existence only in the imagination and shared by a collective. The collective imaginary has been studied in numerous ways by social scientists (Jameson, 1981; Maffesoli, 1996; Taylor, 2004), psychoanalysts (Castoriadis, 1987; Hopper, 2001), and philosopher (Jung, 1986; Bachelard, 1943; Durand, 1969; Wunenburger, 1979). Thus, our contribution aims to investigate the dynamics of expectations and the related role of imagination in the case of the space industry. The space industry is one of the most exemplary cases to study the role of expectations (space observation, space exploration, the conquest of space, etc.), and imagination 
(the "desirable unknown") has always been a strong stimulus for design efforts. With this case, our research addresses the following research questions:

- What has been the role of expectations in the history of the space industry in shaping scientific and technological change, since it is a very constrained area and has developed a strong dominant design?

- What is the relationship among imagination, expectations and materiality? What are the routes of transmission among expectations, embodiment and materiality?

- What are the methods required to trace and to describe the mechanisms of renewal at the intersection of expectations, imagination and projects? Are they on technology? On action? Or on application?

Furthermore, we aim to provide a new approach to deepen one's understanding of the mechanisms of renewal at the crossroads of expectations, imagination and projects. In the literature, there are many ways and methods to study the dynamics of expectations (Van Lente, 1993; Borup et al., 2006). For example, in the social science, studies have shown the important role of expectation in establishing new scientific and technological fields. In economics, the dynamic of expectation studies demonstrate significant results in the context of market behaviour and in technology diffusion. We can also find studies following the approaches of evolutionary economics, actor network, cultural studies of technology, etc (Van Lente, 1993). However, how to explain the convergence of interests of the various actors regarding the proposition of the future? Moreover, how to explain the accession process concerning the common future? Thus, the second objective is to highlight the role of collective imaginary in the dynamics of expectations. Our assumption is that collective imaginary structures the expectations. In essence they allow you to make promises about future and cause fads. In this paper, we propose a new approach and a new theoretical framework (C-K Design theory) in order to highlight the dynamics of expectations and collective imaginary in innovation and technology development. The following section begins with an introduction of the theoretical background. The methodology and C-K design theory used in the case study are then developed and followed by the exploration the dynamics of expectations and imaginaries in the space industry. To conclude, we propose a discussion and final thoughts about the insights gained from our case study.

\section{Theoretical Background}

The phenomenon of expectation has become a crucial issue to understanding innovation capacities and new product development. Expectations are recognized to play a critical role in radical systems innovation (Smith et al. 2010), as underlined by Van Lente (Van Lente, 1993), expectation and vision play a central role in mobilizing resources for technological and innovation development. According to Van Lente (Van Lente, 1993), the general aim of expectation studies is to contribute to understanding the following questions: How does technology gets it shape? How does technology development take place? What are the processes and mechanisms that give technology and technological development its actual configuration?

To study the dynamic of expectation, Van Lente proposes to use a framework: the triangle of technological development (see figure 1). The aim is to represent technological development as involving "artefacts", "actors" and "agenda". 


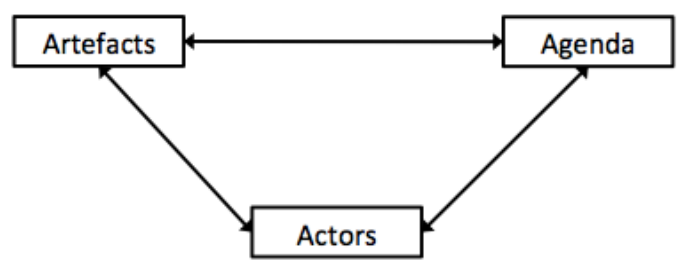

Figure 1: The triangle of technological development

To understand the dynamic of expectation, these three corners are involved and technological development studies have to take them into account. Moreover, Van Merkerk and Robinson show how to characterize the emergence of a technological field using a triad of expectations (artefacts), agenda setting and emerging networks (actors) (Van Merkerk and Robinson, 2006). They introduce the concept of "emerging irreversibilities" to identify, understand and measure the interplay of these three features and the consequences for the possible emerging path in order to learn how to manage this phenomena. Van Lente also defines the mutuality of expectations as the dynamics of "promise and requirement", i.e. engagements become part of a shared agenda and required actions (Borup et al., 2006). Even if a promise does not necessarily imply a responsibility, the sentence "T promise $X$ " is not just a description. Indeed, the person who annunciates this phrase has to justify the future-oriented issues. However, shared expectations can also be used to justify other statements and actions. In more concrete situations, expressing an expectation, say about the usefulness of a tool or a procedure, can be interpreted as an implied warrants to others that they should use that tool or the procedure (Borup et al., 2006). In this sense, expectations are obligatory and allow the emergence of new potential promises for the future. These kinds of dynamics have an important role to play in the earliest stages of innovation and technological development.

Expectations have also a temporal dynamic, which manifest in alternating cycles of hype and disappointment. Indeed, these phenomena of expectations are not necessarily positive. The emerging of expectation supposes to create hype, but as underlined by several authors (Le Masson et al., 2012; Borup et al., 2006; Callon, 1992), it can also generate disappointment. Furthermore, Brown shows, that the number of successive disappointments in areas such as biotechnology, e-commerce and naotechnology have resulted in lasting damage to the credibility of industry, professional groups and investment markets (Brown, 2003). However, when promise are unmet, and expectations are not fulfilled; new promises have to be created. When a promise is accepted, shared by different actors and becomes part of a joint program, other more detailed expectations have to be articulated and taken up. Van Lente (in Brown et al., 2000) demonstrate the salient role of the encompassing promise of technology, in order to protect more specific promises providing a protected space. Further, this notion of "encompassing promise of technology" is a culturally anchored notion, which illustrate that technology will offer possibilities for progress. "Here, the promise of technology as such results in a 'mandate' to technologists: the freedom to explore and develop combined with a societal obligation to deliver in the end." (Borup et al., 2006).

Expectations are spread in different ways and forms. For example, Berkhout highlights the importance of expectations as 'bids' about what the future might be like, that are deployed by agents in order to organise a process of coalition and coordination (Berkhout, 2006). Konrad, in his article, identifies dynamics between specific expectations and collective expectations (Konrad, 2006). Then, Eames and McDowell, through the study of the hydrogen economy, illustrate the interaction between generic and local expectation (Eames and McDowell, 2010). In Geels and Raven's biogas case (Geels and Raven, 2006), the authors study the interaction between local projects and global niches. Other, one of the key issues about the dynamic of expecation are the relationship between imagination and materiality, i.e. the transmission mechanisms between 
expectations, embodiment and materiality. There are a lot of example which it's possible to explore the dynamics between the imagination and materiality. For example, Brown and Kraft propose to think about the precious roles of hopes, affectivity and imaginings in order to analyse the dynamic of expectation (Brown and Kraft, 2006). Finally, expectations allow managing activities, attracting interest and foster investment and providing structure and legitimation. They attribute definition to roles, clarify duties and give a common perception of what to expect and how to anticipate opportunities and risks. They also help to mobilize resources and to build bridges across boundaries, between communities or groups, between different levels or scales and different times.

However, the literature doesn't explain why promises with diffuse scenarios about possible technology and innovation, can be accepted? Indeed, normally when we think about new technologies, innovation and a world of increasing complexity, there are a lot of tensions and divisions. The expression "creative destruction", popularized by Schumpeter, illustrates the incessant product and process innovation mechanism by which new production units replace outdated ones and also refers to the important transformations and changes that accompany innovations. Moreover, Kwasnicki W \& Kwasnicka H (1992) explain that the firms' decisions relating to investment, production, research funds, etc. are taken simultaneously and independently by all firms at the beginning of each period. Then, products are evaluated and selected by the market. The "technology diffusion" literature also highlight phenomenon called "battles for dominance" between rival technologies, often involving firms operating in highly visible industries (Suarez, 2004). A lot of example such as the high definition TV, PC operating system, modem, and Internet browsers contributed to the popularity of "standards wars" and network effects (Arthur, 1998). When President Kennedy says the following promise in 1962 "We choose to go to the moon. We choose to go to the moon in this decade", this underlines the importance of addressing the following questions: what's happen before technological promised? How do we explain that a promise is convincing? How can we understand this promise? Why can we believe this promise? How to explain the accession process about common future? In this paper, we argue that collective imaginary have a fundamental role in the dynamic of expectation: collective imaginary generates, guides and renews expectations. According to Mordini (2007), the role of fantasies and imagination in the constitution of the collective should be traced to Emile Durkheim's work The Elementary Forms of Religious Life (Durkheim, 2013) and to Gustav Jung's research on the collective unconscious (Jung, 1970). Further, the collective imaginary has been studied in different ways by social scientists (Jameson, 1981; Maffesoli, 1996; Taylor, 2004), psychoanalysts (Castoriadis, 1987; Hopper, 2001), and philosopher (Jung, 1986; Bachelard, 1943; Durand, 1969; Wunenburger, 1979). Though from different perspectives, these works suggest that "collective action emerges from the social imaginary, a kind of symbolic template or cultural conditioning that generates a sense of identity and inclusiveness between the members of a group or community" (Mordini, 2007). The collective imagination is a kind of common understanding, which allows people to engage in collective practices. Each person is related to a prefabricated environment in which they are influenced by complex system of messages and stimuli. By birth, assimilation or realization, individuals belong to several groups and each group influences the beliefs, values, attitudes and perceptions of individuals. Each group expresses its own social imaginary in terms of discourse and symbolic formations such as rituals, ceremonies, myths, stories and more. "Social imaginary acts as a filter for new information: it is the lens through which people perceive the world" (Mordini, 2007).

Thus, we propose to analyze the dynamics between the imaginaries and expectation. We think, that the space sector retrospective case study is one of the most interesting cases to study the role of expectations (space observation, space exploration, the conquest of space, etc.) and imaginaries (the "desirable unknown"). With this case, our research addresses two important objectives. First, we try to provide a better understanding of the dynamics of expectation and collective imaginary through the following questions: What has been the role of expectations and imaginaries in the history of space industry in shaping scientific and technological change? What 
is the relationship between collective imaginary and expectations? Second, we attempt to answer the following questions: Can we organize the work on the imaginaries? Is it possible to exchange in the unknown? In this way, we propose a new approach and a new theoretical framework (C-K Design theory) in order to highlight the dynamics of expectation and collective imaginary in innovation and technology development. To follow the design of new vision and promise, we think that $\mathrm{C}-\mathrm{K}$ design theory is one of the most advanced frameworks to bring highlight in understanding of the dynamic between collective imaginary and expectation and in understanding of the difference between looking into the future (i.e. focused attention on prediction) and looking at the future (i.e. possible prediction) (Brown et al., 2000; Borup et al. 2006).

\section{Research Methodology}

\section{Method to Investigate Emerging Fields}

The research method is an inductive, in-depth "ex-post" case study of several space projects. We use an exploratory approach based on grounded theory building (David and Hatchuel, 2007; Eisenhardt, 1989; Glaser and Strauss, 1967). Despite the fact that single case study methods make general empirical validation impossible, they can nonetheless reveal interesting phenomena and provide opportunities for learning (Siggelkow, 2007). Concerning data sources, our analyses are only based on archive, reports, and articles review; which covers various sources of information: Historical works, including space industry and space exploration; biographical works on the main actors of the early decades of the space age; reports and analysis on the space industry to understand the challenges and prospects of development of this sector; the archives of NASA to study the notes and recommendations of the agency in terms of space policy according to time and context; articles in political science, particularly in geopolitical and geo-economics; articles in sociology, particularly to understand relationship between travel and Man (See Appendix 1 to have an overview of the main data sources). In order to structure the data, we adopt a "three level framework" (Van Merkerk and Van Lente, 2005; Van Merkerk and Robinson, 2006). This framework aims to structure data in such a way that the possibility to observe patterns in the data is improved. This tool has been used to structure heterogeneous data in order to investigate "emerging irreversibilities", i.e. investigate "phenomena that facilitate path emergence" (Van Merkerk and Van Lente, 2005; Van Merkerk and Robinson, 2006). Main sources for the desk research are show in Figure 2. This "three-level framework" distinguishes two different core domain of technological activity: basic research and research for market application. These domains are divided into three various levels: (1) within firms or research group, (2) more general, within a technical-scientific field, and (3) more global, in society at large. The first level illustrates the processes between and within research groups and firms. Researches are about specific and varying subjects. Thus, certain topics on which research groups' work together can be used established companies and startups. The second level is about technological field (conferences, review article, technical and scientific communities). The third level refers to the societal level. In this level, governments, interest groups and other societal actors develop the social, economic and political aspects of the new technological field. Obviously, the different levels influence each other in various ways (Van Merkerk and Robinson, 2006). Moreover, each level has not the same timescales: indeed, changes at the level of research groups are faster than changes at societal level (Rip and Kemp, 1998). 


\begin{tabular}{|c|c|c|}
\hline & Basic research & Research for Market Application \\
\hline Society & $\begin{array}{l}\text { - Reports by NGOs and interest groups } \\
\text { (United Nations, UNESCO, etc.) } \\
\text { - Reports by government agencies (NASA, } \\
\text { CNES) } \\
\text { - Spokesperson statements (Kennedy speech) } \\
\text { - Artiles in the press }\end{array}$ & $\begin{array}{l}\text { - Reports by NGOs and interest groups } \\
\text { - Reports by government agencies (NASA, } \\
\text { CNES) } \\
\text { - Spokesperson statements }\end{array}$ \\
\hline $\begin{array}{l}\text { Technological } \\
\text { field }\end{array}$ & $\begin{array}{l}\text { - Review articles that give an overview of the } \\
\text { developments in the field } \\
\text { - Reports on research consortia } \\
\text { - Technical reports } \\
\text { - Archives of NASA }\end{array}$ & $\begin{array}{l}\text { - Reports that translate technological } \\
\text { development into market potentials } \\
\text { - Articles addressing the market potentials of } \\
\text { technological developments }\end{array}$ \\
\hline Reserach group & - Articles in scientific journals & $\begin{array}{l}\text { - Press releases of individual firms } \\
\text { - Articles that address the developement and } \\
\text { potentials applications }\end{array}$ \\
\hline
\end{tabular}

Figure 2: A tree-level framework filled-in with data sources (Van Merkerk \& Robinson, 2006)

Expectations circulate in many different forms and shapes. Thus, one critical issue in our work is the ability to illustrate and to analyze the relationship between imagination, materiality and embodiment. So, in order to follow the design of new visions and promises, we propose to use the most recent models of design reasoning (C-K design theory) (Hatchuel and Weil 2003), which generalize classic engineering design models (Pahl and Beitz 2006) and search models (Hatchuel 2002; Simon 1969).

\section{Theoretical Framework: C-K Design Theory}

Hatchuel and Weil introduced the C-K theory in 2003 (Hatchuel and Weil 2003, 2008). This theory aims to provide a unified and rigorous framework for design. Other, Hatchuel (2001), Hatchuel and Weil (2003, 2008), Kazakçi and Tsoukias (2005), Elmquist and Segrestin (2007), Elmquist and Le Masson (2009), and Le Masson, Aggeri, Barbier, and Caron (2012) also attempt to provide a better understanding of innovative design with using C-K Theory. According C-K design theory, design is defined as "an interplay between two interdependent spaces", the space of concepts $(C)$ and the space of knowledge $(K)$.

$\mathrm{K}$ Space incorporates all the propositions with a logical status, i.e. all available knowledge that the designers are able to prove or disprove (e.g., technical and scientific knowledge, market issues, and standards).

On the other hand, C Space includes all the propositions neither true nor false in $\mathrm{K}$ space, i.e. concepts about partially unknown objects. Propositions in $\mathrm{C}$ space are qualified as "undecidable" relative to the content of a space $\mathrm{K}$ if it is not possible to prove that these propositions are true or false in $\mathrm{K}$ space. When designers are faced with concepts (i.e. manned spacecraft to explore Mars), designers cannot affirm whether such a thing may be possible or that this would never be the case.

According the $\mathrm{C}-\mathrm{K}$ theory, design starts when an initial concept is created. Design process proceeds by expansion of this initial concept into other concepts (by partitioning the concept) and/or into new knowledge. During the design process, both $\mathrm{C}$ and $\mathrm{K}$ spaces are expandable and these transformations between spaces and in the same spaces take place through four operations: $C \rightarrow C, C \rightarrow K, K \rightarrow K$ and $K \rightarrow C$ (Figure 1). 


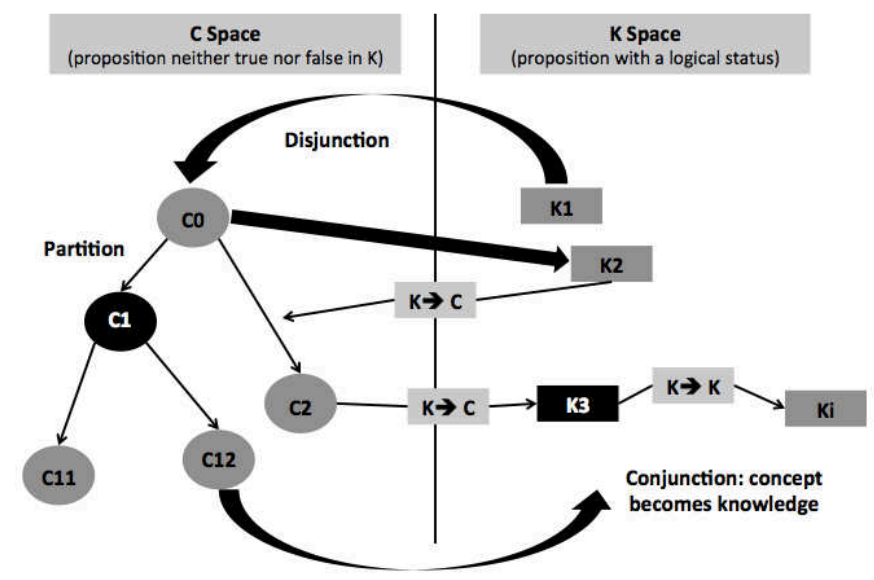

Figure 3: C-K Design Formalism (Hatchuel \& Weil, 2003)

The design process attempts to transform "undecidable" propositions into logical propositions in $\mathrm{K}$, i.e. the design solution is when "the first concept become a true proposition in K" (a conjunction). Moreover, these two spaces ( $\mathrm{C}$ and $\mathrm{K}$ ) have a different structure. The $\mathrm{K}$ space evolves like "an archipelado": new propositions are added without following a stable order or being connected directly (Hatchuel et al., 2009). Unlike, C space has a determined structure: this space has a tree structure. Each node represents a partition in divers sub-concepts (Hatchuel and Weil, 2003), and only partitioning or inclusions are allowed in C space. The theory introduces two different types for partitioning for concepts: restrictive partitions and expanding partitions (Hatchuel and Weil, 2003). Restrictive partitions add a property to a concept already known, unlike expanding partitions, which add properties not know in $\mathrm{K}$ as a property of the entities concerned. Therefore, "creativity and innovation are due to expanding partitions of concepts". Then, design process has to be understood as interactions between these two spaces. Knowledge is used to elaborate concepts in $\mathrm{C}$ space, and concepts are used to expand and to expand knowledge in $\mathrm{K}$ space. Design process ends when undecidable proposition (concept) become decidable in $\mathrm{K}$ space.

Method to analyse collective imaginary

To analyse collective imaginary, we decide to use the theoretical framework proposed by Bouchard (Bouchard, 2003, 2013). Bouchard conceives collective imaginary as a set of representations by which any community give a definition of itself and others, in the past, present and future. Bouchard highlights two ways to represent the collective imaginary: the act of constructing representations and the representations themselves that are the symbolic product. The representation of collective imaginary production, i.e. the collective imaginary design process, refers to the following concepts: production of meaning, argumentation, rhetoric, positive knowledge, fiction and myth. This vision of the imagination is expressed through several vectors ranging from literature and cinema to philosophy and theology. Each vector leads to expand the collective imaginary of its representations. Concerning the collective imaginary, as a symbolic product offered for the social use, it refers to the following expressions: mythologies, traditions and customs, religion, identity, memory, ideology, knowledge, etc. 


\begin{tabular}{|c|c|c|}
\hline $\begin{array}{l}\text { Imaginary development, as a } \\
\text { blend of reason and myth }\end{array}$ & \multirow{9}{*}{$<==>$} & $\begin{array}{c}\text { Imaginary, as a symbolic product } \\
\text { offered for social use }\end{array}$ \\
\hline Vectors: & & Expressions: \\
\hline Arts (theater, cinema, painting, etc.) & & Mythologies \\
\hline Literature (poetry, novel, story, etc.) & & Traditions and customs \\
\hline $\begin{array}{c}\text { Sciences (historiography, philosophy, } \\
\text { theology, etc.) }\end{array}$ & & Religions \\
\hline \multirow{4}{*}{$\begin{array}{l}\tilde{\mathrm{n}} \\
\text { Primary culture, the field of the } \\
\text { unconscious and of psychism }\end{array}$} & & Identity \\
\hline & & Memory \\
\hline & & Stereotypes \\
\hline & & Knowledge, Ideology \\
\hline
\end{tabular}

Figure 4 : Theoretical framework proposed by Bouchard (Bouchard, 2003)

\section{Study: Exploring the Dynamics of Expectations and Imaginaries in the Space Industry}

\section{The beginning of the conquest of space}

In 1952, the International Council of Scientific Unions, proposed to coordinate a set of research to increase the knowledge of physical properties of the Earth and the interactions between the Sun and our planet. The project was named "International Geophysical Year"(IGY) and took place between July 1957 and December 1958. On this occasion, it was suggested to launch into orbit small scientific equipment, to record certain phenomena in the upper atmosphere and space. In 1956, the United States and the Soviet Union announced their intentions to launch an artificial satellite. In proposing this project, members of CSAGI (special committee of the IGY) knew recent in launching rockets and missiles. Thus, in their view, the project was feasible. Indeed, preliminary work, performed independently in the United States and the USSR, convinced the specialists from both countries that this project did not raise insurmountable technical difficulties. The U.S. program, the "Vanguard Project" was made public after a press conference in 1956. A credit of $\$ 20$ million was voted for its implementation, with the full approval of President Eisenhower. Against all odds, Oct. 4, 1957, the Soviets were the first to launch a satellite into orbit: Sputnik 1. Following the launch of Sputnik, the CIA director said to the White House press secretary: "The launching by the Soviet Union of the first earth satellite is an event of considerable technical and scientific importance. [...] What has happened involves no basic discovery and the value of a satellite to mankind will for a long time be bighly problematical'”. In March 1958, the Scientific Advisory Committee to the President of the United States introduced a note on the following topic: Introduction to Outer Space. The objective was to determine the direction and the appropriate pace of future space programs of the United States and answer the following questions: What are the principal reasons for undertaking a national space program? What can we expect to gain from space science and exploration? What are the scientific laws and facts and the technological means, which it would be helpful to know and understand in reaching sound policy decisions for a United States space program and its management by the Federal Government? In this report, the Scientific Advisory Committee of the President of the United States, distinguishes four factors that illustrate the importance, urgency and inevitability of developing a space program: The first of these factors is the compelling urge of man to explore and to discover, the thrust of curiosity that leads men to try to go where no one has gone before. Second, there is the defense objective for the development of space technology. Third, there is the factor of national prestige. Fourth, space technology affords new opportunities for scientific observation and 
experiment. Three months after the first note, the National Security Council publishes a new note identifying the most important parameters to consider about this new space age: "(1) the USSR has surpassed the United States and the Free World in scientific and technological accomplishments in outer space, which have captured the imagination and admiration of the world; (2) the USSR, if it maintains its present superiority in the exploitation of outer space, will be able to use that superiority as a means of undermining the prestige and leadership of the United States; and (3) the USSR, if it should be the first to achieve a significantly superior military capability in outer space, could create an imbalance of power in favor of the SinoSoviet Bloc and pose a direct military threat to U.S. security. The security of the United States requires that we meet these challenges with resourcefulness and vigor'".

At this time, the stakes of prestige and national defense become more important than scientific issues. The race to conquer space is started and it will mainly be confined to technological issues and ideological prestige. The USSR, which has an important advance, continues to multiply the first exploits: first satellite in orbit, first living being in space, first lunar probe, first man in space, etc. Very quickly, it becomes imperative for US to realize a first space exploit. At this time, there is already a specific space exploration imaginary (which exists only in the imagination, which has no reality) that is largely developed: manned exploration of space (seventeenth century), spaceships (seventeenth century), solar system exploration (seventeenth century), the conquest of a planet by humans (seventeenth century), device landing on the planets (1928), multi-stage rocket (1927), space station in Earth orbit (1923), communication and Earth observation satellites (1945), etc. (See appendix 2 for more information about existing concepts). On the other, it is important to note that the emergence of science fiction, as a literary genre, represents a turning point in the appropriation, by the population, of space exploration issue. The writer Robert A. Heinlein (1907-1988) exerted a great influence on the American people about the conquest of space, particularly through the works: The Man Who Sold The Moon (1951) and the movie Destination Moon (1950). In addition, at the same time, the British author Arthur C. Clarke (1917-2008), in his novels Prelude in the Sky (1951) and Islands in the Sky (1952), also contributes to evangelize its readership to conquer space. In 2007, Michael Griffin, NASA Administrator (20052009), said about the conquest of the Moon: "In general, the great early authors of hard science-fiction, I think, created a climate in which it became ultimately possible to talk about putting people in space, about going to the Moon, about going to Mars"'. Thus, we show that the set of goals that will be set by the USSR and the USA, refer to concepts invented before 1957.

\begin{tabular}{|c|c|c|}
\hline $\begin{array}{l}\text { Imaginary development, as a } \\
\text { blend of reason and myth }\end{array}$ & & $\begin{array}{l}\text { Imaginary, as a symbolic product } \\
\text { offered for social use }\end{array}$ \\
\hline $\begin{array}{l}\text { Vectors: } \\
\end{array}$ & & Expressions: \\
\hline $\begin{array}{l}\text { Cinema: The Man Who Sold The Moon } \\
\text { (1951), Destination Moon (1950) }\end{array}$ & & Ideology: Capitalism, communism \\
\hline $\begin{array}{l}\text { Literature: Science-fiction, Jules } \\
\text { Verne, Robert A. Heinlein }\end{array}$ & $<==>$ & $\begin{array}{l}\text { Mythologies: conquest of the West, } \\
\text { exploration, the mythology of travel, } \\
\text { hero }\end{array}$ \\
\hline $\begin{array}{l}\text { Sciences: Tsiolkovski, The } \\
\text { Exploration of Cosmic Space by } \\
\text { Means of Reaction Devices (1903); } \\
\text { Oberth, By Rocket into planetary } \\
\text { space (1923) }\end{array}$ & & Memory: World war II \\
\hline $\begin{array}{l}\text { Primary culture, the field of the } \\
\text { unconscious and of psychism }\end{array}$ & & Knowledge: nuclear, electronic, etc. \\
\hline
\end{tabular}


Stereotypes: the free world,

nationalism and totalitarianism

Figure 5: Collective imaginary between 1900 and 1970

Between 1957 and 1975, the design process is confined to tap into the collective imaginary available, thereby limiting exploration efforts for new alternatives and the introduction of new dimensions in design. The design process relied primarily on a system of design rules, evolving in successive projects to achieve the various existing concepts (See Appendix 3: The design process of the conquest of space, with CK theory). The case of the conquest of the moon particularly illustrates this assertion.

The case of the conquest of the Moon: use a collective imaginary to build a dynamic of expectation

April 12, 1961, the Soviet Yuri Gagarin became the first man to make a space flight. Following this new Soviet feat, U.S. President John F. Kennedy published a memorandum with the objective of determining a spatial program that can finally bring victory to the United States (See Appendix 4: John F. Kennedy, Memorandum for Vice President, April 20, 1961): "In accordance with our conversation I would like for you as Chairman of the Space Council to be in charge of making an overall survey of where we stand in space.

1. Do we have a chance of beating the Soviets by putting a laboratory in space, or by a trip around the moon, or by a rocket to land on the moon, or by a rocket to go to the moon and back with a man. Is there any other space program which promises dramatic results in which we could win?

2. How much additional would it cost?

3. Are we working 24 hours a day on existing programs. If not, why not? If not, will you make recommendations to me as to how work can be speeded up.

4. In building large boosters should we put our emphasis on nuclear, chemical or liquid fuel, or a combination of these three?

5. Are we making maximum effort? Are we achieving necessary results? I have asked Jim Webb, Dr. Weisner, Secretary McNamara and other responsible officials to cooperate with you fully. I would appreciate a report on this at the earliest possible moment."

April 28, 1961, Vice President Lyndon B. Johnson, answered: "Manned exploration of the moon, for example, is not only an achievement with great propaganda value, but it is essential as an objective whether or not we are first in its accomplishment-and we may be able to be first. [...] Hence they might be conceded a time advantage in circumnavigation of the moon and also in a manned trip to the moon. However, with a strong effort, the United States could conceivably be first in those two accomplishments by 1966 or 1967."

10 days later, James E. Webb (NASA Administrator) and Robert S. McNamara (Secretary of Defense) proposed for the first time, the man's conquest of the moon as a priority of the U.S. space program. The project was called Apollo: "To achieve the goal of landing a man on the moon and returning him to earth in the latter part of the current decade requires immediate initiation of an accelerated program of spacecraft development. The program designated Project Apollo includes initial flights of a multimanned orbiting laboratory to qualify the spacecraft, and manned flights around the moon before attempting the difficult lunar landing. " Finally, the memorandum Kennedy was the starting point of the Apollo program. By asking the question: "Is there any other space program which promises dramatic results in which we could win?", President Kennedy set in motion a dynamic of expectation. September 12, 1962, Kennedy gave his famous speech on the conquest of the Moon: "We choose to go to the moon. We choose to go to the moon in this decade [...]."

In July 1969, the Apollo 11 mission allows American to walk on the Moon. This spectacular achievement allowed the United States to win the space race. In 1975, after the Apollo 17 mission, the U.S. abandoned the lunar program: There was nothing more to prove. 


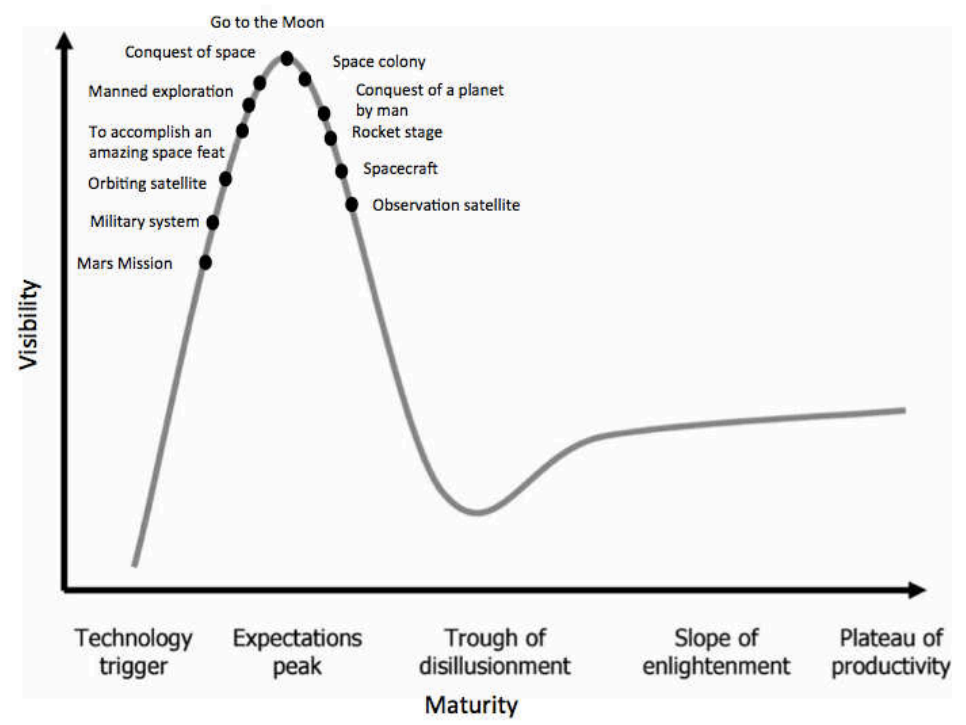

Figure 6: The Gartner « hype cycle ", "The paradigm of conquest of space" (1957-1975)

\section{Renewal of imaginaries and expectations}

From 1970, a new collective imaginary will gradually emerge and change the place of space in our society. The major technological prowess will be left to the profits of a collective imaginary, promoting concepts seeking to improve the development of society and respect for the environment. This new period is characterized by a new design effort focused on space applications that can be at the service of society and sustainable development. Thus, concepts such as "global communication", "global medicine", "Space at the service of agriculture", "Space to understand Earth", etc., are breaking with concepts of the first era of space exploration. (See appendix 5: "A return to planet Earth?"(1975-2011) with C-K diagram) All these new concepts are echoed in the awareness of the fragility of the Earth's ecosystem. In 1983, the German astronaut Ulf Merbold highlighted this fragility: "For the first time in my life I saw the horizon as a curved line. It was accentuated by a thin seam of dark blue light our atmosphere. Obviously this was not the ocean of air I had been told it was so many times in my life. I was terrified by its fragile appearance". One can also find the will of renewal imaginaries and expectations in a first report dated September 1969:

- "Increase utilization of space capabilities for services to man, through an expanded space applications program;

- Enhance the defense posture of the United States and thereby support the broader objective of peace and security for the world through a program which exploits space techniques for accomplishment of military missions;

- Increase man's knowledge of the universe by conduct of a continuing strong pro-gram of lunar and planetary exploration, astronomy, physics, the earth and life sciences;

- Develop new systems and technology for space operations with emphasis upon the critical factors of: (1) commonality, (2) reusability, and (3) economy, through a program directed initially toward development of a new space transportation capability and space station modules which utilize this new capability;

- Promote a sense of world community through a program, which provides opportunity for broad international participation and cooperation. $\|^{8}$

In addition, the 1970s will not be conducive to budget increases. Indeed, the first oil shock of 1973 and the second oil shock in 1979 will have major impacts on the global economy and in particular the U.S. economy. However, in 1975, the Helsinki Accords participated in improving relations between the Communist bloc and the West. Finally, new international aspirations and expectations made their appearances. The United Nations Conference on the 
Environment in Stockholm (1972) placed, for the first time, environmental issues to the level of international concern and proposed a comprehensive plan of action to fight against pollution.

\begin{tabular}{|c|c|c|}
\hline $\begin{array}{l}\text { Imaginary development, as a } \\
\text { blend of reason and myth }\end{array}$ & \multirow{4}{*}{$<==>$} & $\begin{array}{c}\text { Imaginary, as a symbolic product } \\
\text { offered for social use }\end{array}$ \\
\hline Vectors: & & Expressions: \\
\hline $\begin{array}{l}\text { Arts (surrealism, Land Art, } \\
\text { psychedelic music) } \\
\text { Literature (Ionesco, Soljenitsyne) } \\
\text { Sciences (nuclear, electronic, etc.) }\end{array}$ & & $\begin{array}{l}\text { Ideology: end of communism, } \\
\text { ecology, neo-hippies, } \\
\text { Memory: cold war }\end{array}$ \\
\hline $\begin{array}{l}\text { Primary culture, the field of the } \\
\text { unconscious and of psychism }\end{array}$ & & $\begin{array}{l}\text { Knowledge: Astronautic, biochemic, } \\
\text { informatics, etc. }\end{array}$ \\
\hline
\end{tabular}

Figure 7: Collective imaginary between 1970 and 2011

Inevitably, the U.S. and world space policy will be part of this new dynamic. It is in this economic context that the concept of Space Shuttle became the best compromise to boost the exploration and exploitation of space. Space Shuttle means a spacecraft that can return to Earth by performing a controlled landing like a glider and can be reused for a subsequent mission. This new concept is opposed to conventional spacecraft like Apollo and Soyuz, landing with parachutes. The decision, to initiate this program, was based on the following reasons: "There are three reasons why the space shuttle is the right next step [...]. First, the shuttle is the only meaningful new manned space program which can be accomplished on a modest budget. [...] Second, the space shuttle is needed to make space operations less complex and less costly. [...] Third, the space shuttle is needed to do useful things. The long term need is clear. In the 1980's and beyond, the low cost to orbit the shuttle gives is essential for all the dramatic and practical future programs we can conceive."

This period of history illustrates the revival of imaginaries and expectations in the space sector. This retrospective analysis illustrates the fact that within the same industry, imaginaries directly affect the dynamics of expectations. Furthermore, these imaginaries are dependent on actors who suggest them, as well as external conditions (economic, political, social, etc.). 


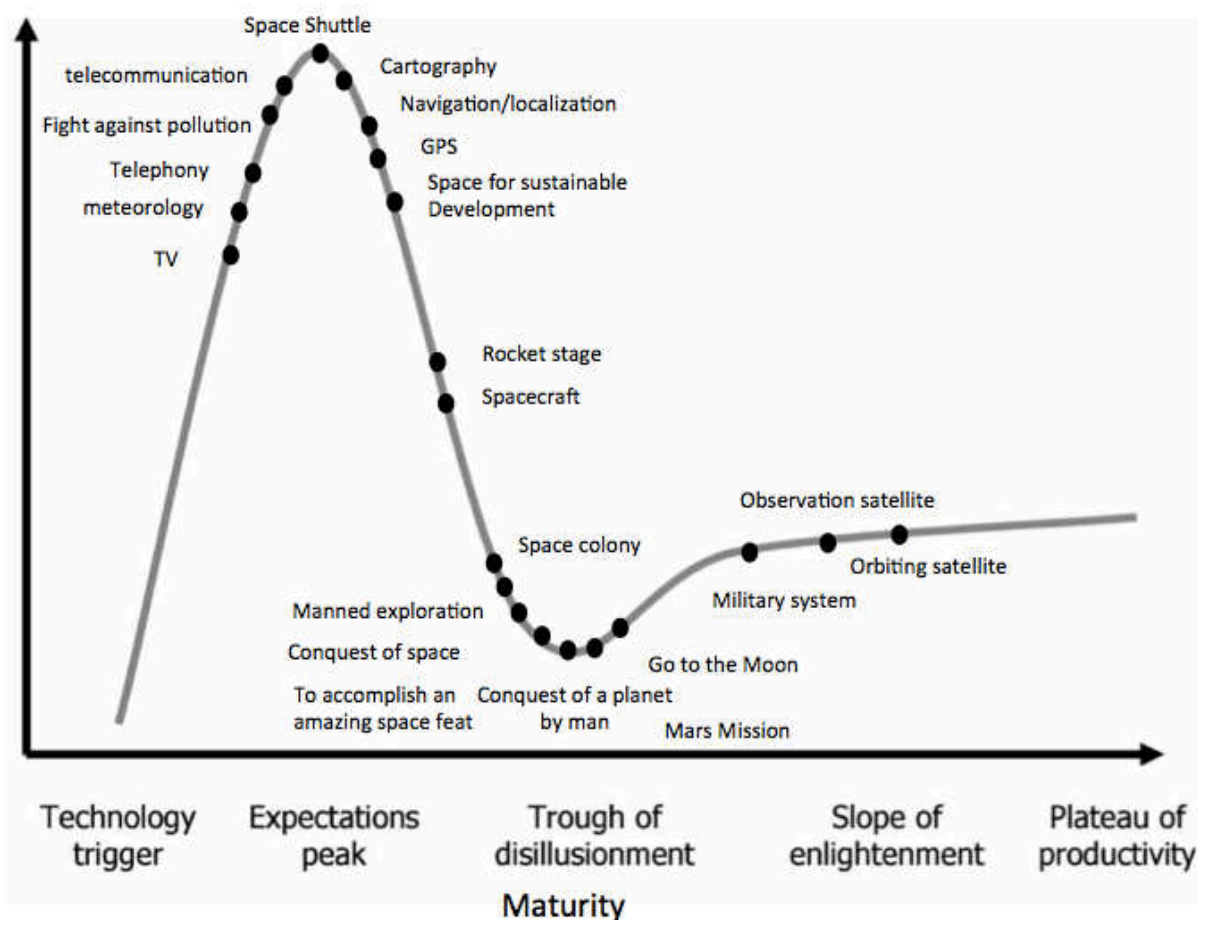

Figure 8 : The Gartner « hype cycle », "A return to planet Earth?"(1975-2011)

\section{New actors for renewal imaginaries and expectations}

Since the 2000s, new actors have made their appearances. Most of these new actors are positioned on radical new concepts: Space Tourism, tourist space station, exploitation of natural resources in space, system capable of intercepting an asteroid. What is particularly interesting in this new generation of entrepreneur is the cooperation and synergy between these new projects. Moreover, the profile of these entrepreneurs is extremely similar. Most of them are former entrepreneurs who have created the largest companies of the digital economy (Paypal, Google, Microsoft, Facebook, Amazon). All their past experiences and the close links among them, contribute to the creation of an informal network, a kind of "college of the unknown" (Le Masson et al., 2012) connecting entrepreneurs, investors, designers and promoters. 


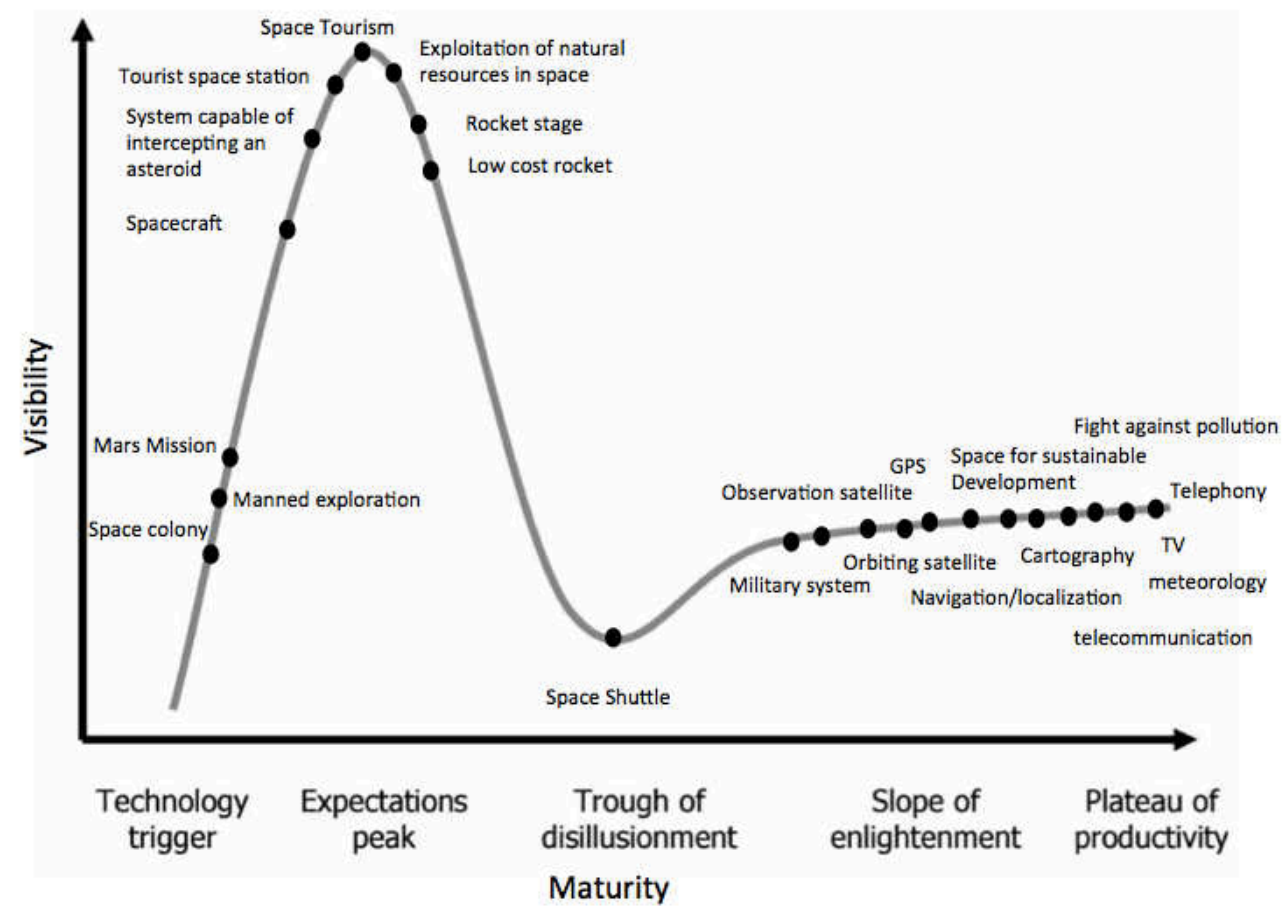

Figure 9 : The Gartner « hype cycle », renewal of expectations (2011-...)

These actors do not necessarily share competences, they think and exchange about the nature of the open questions, unsolved problems and critical challenges. In this "exchange in the unknown", some actors provide "ideas" and "stimuli" to support the design activities of other actors. However, this college is not oriented toward one scientific field but to the exploration of emerging technologies and the sustained renewal of imagination and expectation. Le Masson et al. (Le Masson et al., 2012) label this type of organization a college of the unknown, by analogy with the "invisible colleges" of Diana Crane (Crane 1972) who, studying research networks, noticed that a clique of researchers with direct and indirect links were influencing the works of the rest of the community. On the other, analysing the fortune of these principal actors shows the high financial potential of these new actors. Indeed, the NASA budget (\$17,770 million in 2012) represents only $15.7 \%$ of their total wealth ${ }^{10}$.

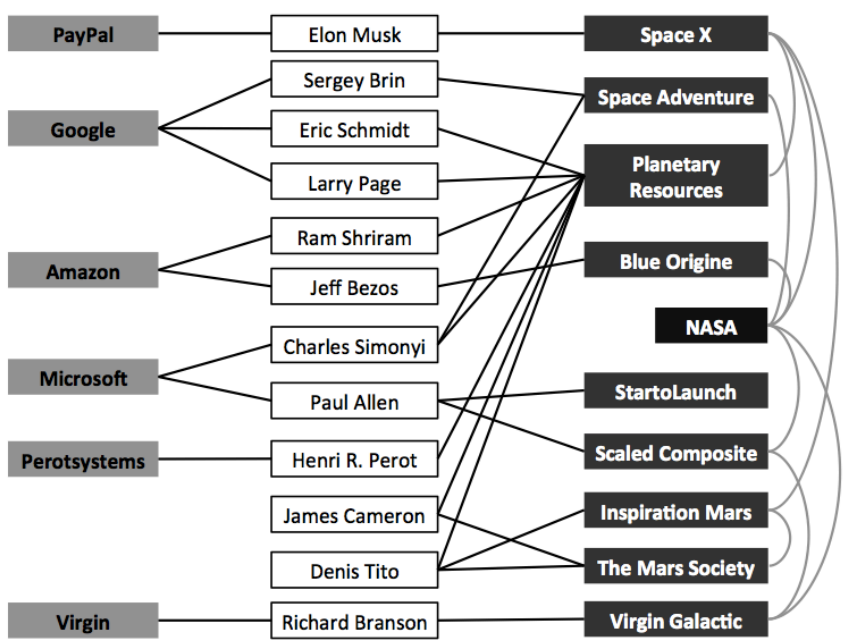

Figure 10: New actors and new companies 


\section{Conclusion and Perspectives}

First, this case study allows highlighting the wealth of projects and the dynamics of expectations in the space sector. This analysis allowed us to identify the major changes and developments in expectations over time. We propose to consider that the dynamics of expectations, in the space sector, is characterized by three major phases ("The paradigm of the conquest of space" (1957-1975), "A return to planet Earth?"(1975-2011), and finally, the last phase $(2011-\ldots)$ shows a renewal of expectations in the space sector. The example of the Memorandum for Vice President from John F. Kennedy highlights the complex relationship between collective imaginary and expectation. Indeed, in this document, Kennedy asks the question: Which concepts? i.e. which artefacts should we choose to make a promise? This question illustrates the following question: what's happen before technological promised? Kennedy's response: "Go to the Moon" confirms the important role of collective imaginary in the dynamics of expectation. In order to propose such a promise, the establishment of common interests is not enough: There is a need to have a collective imaginary, able to guide expectations. If the "interests" was enough, Kennedy could choose the most reliable and cheapest project. We observe that the imaginaries are more or less structured and it's this richness of imaginary "Go to the Moon" which may explain the response of Kennedy. In addition, we observe that the imaginaries may already be present, or conversely must be proposed and established. After the end of Apollo project, it becomes necessary to design a new collective imaginary in order to renew the space of concepts and thus expectations. As a kind of symbolic template able to generate a vision and a sense of identity between the members of a group or community, imaginaries are a major determinant of the dynamics of expectations: collective imaginary generates, guides and renews expectations. The collective imagination is a kind of common understanding, which allows people to believe, adhere to a promise on the future and to engage in collective practices. On the one hand, the case study shows that future expectations and promise may be envisaged only if there is a collective imaginary. On the other hand, when collective imaginary is exhausted or over, it becomes impossible to formulate new promise, i.e. new expectations. This phenomenon manifested in alternating cycles of hype and disappointment. Thus, it becomes imperative to design a new collective imagination to renew the dynamic of expectations. We argue that disappointment is more the result of a lack of a renewal of collective imaginary, that an unfulfilled promise. A network of researchers, under the banner of "Sociology of Expectation", identified is both a performative element of expectation and an inseparable tie between expectations, anticipatory action and agency (Adam, 2005). They offered observations about formalized way in which futures and expectations are enacted. They also propose to do the difference between looking into the future and looking at the future. According to Borup (Borup \& al., 2006), it's probably the most important next step for analysts of expectations is to bring these two dimensions together in a more reflexive attempt to understand the contribution of their findings for the future underway in the present. We argue that this study allows bringing highlight in a more reflexive attempt to understand interaction between "prediction" (looking into the future, i.e. expectation) and "possible prediction" (looking at the future, i.e. collective imaginary). 

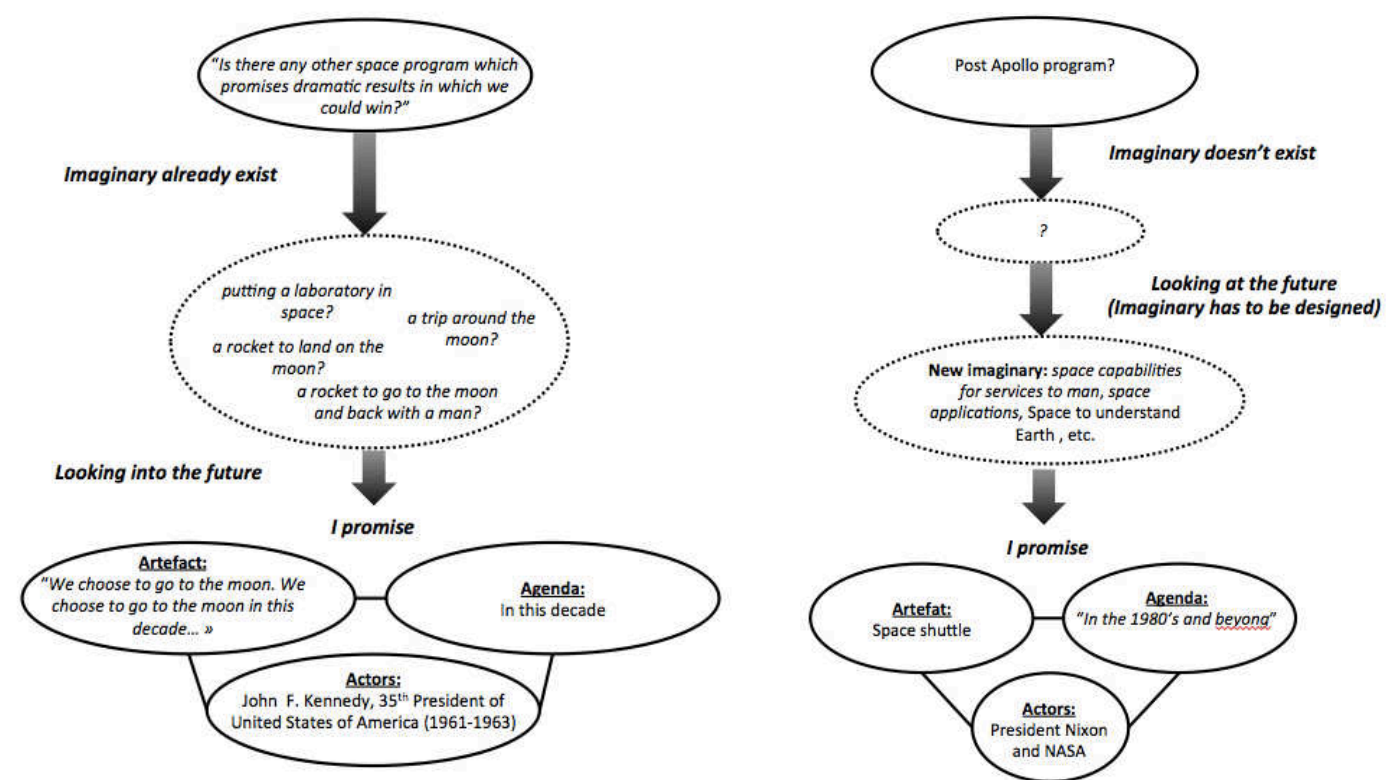

Figure 9: Role of imaginary in the dynamic of expectations

Second, the identification of a college of the unknown who "exchange in the unknown", shows that we can organize the work on the imaginaries. The development of a collective imaginary is neither a change in the real and the representation of a change followed by observation of its effects, but the invention of new possibilities, i.e. the construction of new concepts. Entrepreneurs from the digital economy (Paypal, Google, Microsoft, Facebook, Amazon) shows that it's possible to work and contribute to the creation of a new collective imaginary. Moreover, a recent experience organized by the NASA (International Space Apps Challenge) illustrates the interest that the American space agency have for the renewal of collective imaginary. The International Space Apps Challenge is a hackathon which includes, in 2013, more than 9,000 people in over 44 countries for a total of 83 cities. During the weekend of 20 and 21 April 2013, developers, engineers and designers participated in raising the fifty challenges proposed by NASA including International Print Station (development of a 3D printer model for use in space), Earth from Space (creation of an application that allows you to view the Earth 3D), Curiosity at Home (foster a link between citizens and the rover Curiosity thanks to software, applications or visualizations), We Love Data (rethink the way people interact with the data from space), creation of an application that can determine the origin of a shower of meteorites in real time, etc. During the 2013 event, more than 700 solutions and innovative projects have been identified by NASA. Finally, our results allow highlighting the dynamics of expectation and collective imaginary in innovation and technology development. It is obvious that the knowledge from expectation and collective imaginary studies might be useful to people and firms working on the understanding of technology and innovation management. Thus, it can contribute to an improved and more reflexive handling of innovative product development. Finally, it might be fruitful to examining in greater detail how the findings about expectations and collective imaginary dynamics can be used in prospective and strategic activities and as practical advice for innovation and product development management. 


\section{Acknowledgements}

The authors of this paper would like to thank Elisa Cliquet Moreno, Richard Heidmann, Marie Le Pellec-Dairon, Sylvain Lenfle and Kevin Herlem for their valuable contributions to this paper. This work was carried out with the support of the Chair of Design Theory and Methods for Innovation of MINES ParisTech.

\section{Notes}

${ }^{1}$ John Foster Dulles to James C. Hagerty, October 8, 1957, with attached "Draft Statements on the Soviet Satellite," October 5, 1957.

${ }^{2}$ National Security Council, NSC 5814, “US.Policy on Outer Space,” June 20,1958.

${ }^{3}$ NASA administrator Mike Griffin, the Heinlein Centennial conference on July 6 in Kansas City, Missouri.

${ }^{4} J o h n$ F. Kennedy, Memorandum for Vice President, April 20, 1961.

${ }^{5}$ Lyndon B. Johnson, Vice President, Memorandum for the President, "Evaluationof Space Program," April 28,1961.

${ }^{6}$ James E. Webb, NASA Administrator, and Robert S. McNamara, Secretary of Defense, to the Vice President, May 8, 1961, with attached : "Recommendations for Our National Space Program: Changes, Policies, Goals."

7John F. Kennedy Moon Speech - Rice Stadium, September 12, 1962.

${ }^{8}$ Space Task Group, The Post-Apollo Space Program : Directions for the Future, September 1969.

'James C. Fletcher, “The Space Shuttle”, November 22, 1971

${ }^{10}$ Fortune Magazine (2013)

\section{References}

Adam, B., (2005), Futures in the Making: Contemporary Practices and Sociological Challenges, Conference paper - draft, ASA 2005, Philadelphia, Thematic Session: Sociology of the Future Tue, Aug 16, 2:30 - 4:00, Philadelphia Mariott.

Arthur, B., (1998), Increasing returns and the new world of business, Harvard Business Review 74, 100-110.

Bachelard, G., (1943), L'Air et les Songes : essai sur l'imagination du mowvement, Éditions José Corti, 1943.

Berkhout, F.G.H. (2006), Normative Expectations in Systems Innovation. Technology Analysis \& Strategic Management, vol 18, no3/4, 2006: 299- 311.

Borup, M., N. Brown, K. Konrad and H. Van Lente. 2006. The sociology of expectations in science and technology. Technology Analysis \& Strategic Management 18: 285-98.

Bouchard, G., (2003), Sur la Structure et l'évolution des imaginaires collectifs : quelques propositions, Interfaces Brasil/Canada, Belo Horizonte, V.1, N.3, 2003.

Bouchard, G., (2013), Pour une nouvelle sociologie des mythes sociaux, Un repérage préliminaire, Revue Européenne des sciences sociales, p. 95-120, 2013.

Brown, N. (2003), Hope against hype: accountability in biopasts, presents and futures, Science Studies, 16(2), 2003, pp. 3-21.

Brown, N. and Kraft A. (2006), Blood Ties: Banking the Stem Cell Promise, Technology Analysis \& Strategic Management, 18, (3/4), pp. 313-327 
Brown, N., Rappert, B. \& Webster, A. (2000), Contested Futures: A Sociology of Prospective Techno-Science, Aldershot, UK, Ashgate, 2000.

Callon, M., Laredo, P., and Rabeharisoa, V. (1992), The management and evaluation of technological programs and the dynamics of techno-economic networks: The case of the AFME, Resarch Policy, 21, pp.215-236.

Castoriadis, C., (1987), The Imaginary Institution of Society, Policy Press, 1987.

Crane, D. (1972), Invisible Colleges : Diffusion of knowledge in scientific communities, Chicago : The University of Chicago Press.

David, A. and A. Hatchuel. 2007. From actionable knowledge to universal theory in management research. In Handbook of collaborative management research, 33-48. Thousand Oaks, CA: Sage.

Durand, G., (1969), Les Structures Anthropologiques de l'Imaginaire, Edition Bordas, Paris, 1969.

Durkheim, E (2013), Les formes élémentaires de la vie religieuse, Presse Universitaire de France, Paris, 2013.

Eames \& McDowall (2010), Sustainability, foresight and contested futures: Exploring visions and pathways in the transition to a hydrogen economy. Technology Analysis and Strategic Management 22 (6), pp. 671-692.

Eisenhardt, K.M. (1989). Building Theories from Case Study Research. Academy of Management Review 14(4):532-550.

Elmquist, M. and P. Le Masson. 2009. The value of a 'failed' r\&d project: An emerging evaluation framework for building innovative capabilities. R\&D Management 39: 136-52.

Elmquist, M. and Segrestin, B. (2007). Towards a New Logic for Front End Management: From Drug Discovery to Drug Design in Pharmaceutical R\&D. Creativity and Innovation Management 16(2): 106-120.

Geels, F., and Raven, R. (2006), "Non-linearity and Expectation in Niche-Development Trajectories : Ups and Downs in Dutch Biogas Development (1973-2003)", Technology Analysis \& Strategic Management, 18, (3/4), pp. 375-392.

Glaser, B.G. and Strauss. A.L. (1967), The discovery of grounded theory: Strategies for qualitative research. Chicago: Aldine Publishing Company.

Hatchuel A et Weil B (2009), "C-K Design Theory: An Advanced Formulation", Research in Engineering Design, Vol. 19, pp. 181-192.

Hatchuel, A. 2001. Towards design theory and expandable rationality: The unfinished program of herbert simon. Journal of Management and Governance 5: 260-73.

Hatchuel, A. and Weil, B. (2003). A New Approach of Innovative Design: An Introduction to C$\mathrm{K}$ Theory. Paper presented at the International Conference on Engineering Design, Stockholm, August 19-21.

Hatchuel, A. and Weil, B. (2008). C-K Design Theory: An Advanced Formulation. Research in Engineering Design 19(4):181-192.

Hopper, R., (2001), Housing Imaginations: New concepts, new theories, new researchers. HSA Autumn Conference. British Housing Studies Association Autumn Conference. Cardiff University, September 4th and 5th, 2001.

Jameson, F., (1981), The Political Unconscious: Narrative as a Socially Symbolic Act. Ithaca, N.Y.: Cornell University Press. 1981.

Jung, C.G., (1986), Analytical Psychology: Its Theory \& Practice, Ark Paperbacks, 224 p., 1986.

Kazakçi, A.O. and Tsoukias, A. (2005). Extending the C-K design Theory: A Theoretical Background for Personal Design Assistants. Journal of Engineering Design 16(4): 399_ 411.

Konrad, K. (2006), The Social Dynamics of Expectations: The Interaction of Collective and Actor-Specific Expectations on Electronic Commerce and Interactive Television. Technology Analysis \& Strategic Management, vol 18, no3/4, 2006: 429- 444. 
Kwasnicki, W \& Kwasnicka, H, (1992), Market, innovation, competition: An evolutionary model of industrial dynamics, Journal of Economic Behavior \& Organization, Elsevier, vol. 19(3), pages 343-368, 1992.

Le Masson P, Aggeri F, Barbier M, Caron P (2012) The sustainable fibres of generative expectation management: The "building with hemp" case study. In: Barbier M, Elzen B (eds) System Innovations, Knowledge Regimes, and Design Practices towards Transitions for Sustainable Agriculture. INRA Editions, Paris, pp 226-251

Le Masson, P., Weil, B., Hatchuel, A., \& Cogez, P. (2012). Why aren't they locked in waiting games? Unlocking rules and the ecology of concepts in the semiconductor industry. . Technology Analysis \& Strategic Management, 24(6), 617-630.

Maffesoli , M., (1996), La Contemplation du monde (1993), Le Livre de Poche, 1996.

Mordini, E, (2007). Nanotechnology, society and collective imaginary: setting the research agenda. In Graeme A. Hodge, Diana Bowman, Karinne Ludlow (Eds.), New Global Frontiers in Regulation: The Age of Nanotechnology (pp. 29-48). Monash University Press, 2007.

Pahl, G., and Beitz, W. (2006). Engineering design, a systematic approach, in K. Wallace, L. Blessing, and F. Bauert, translator, Springer, Berlin. 544 p.

Rip A., and Kemp R. (1998), Technological change, in: Rayner \& E.L. Malone (Eds) Human Choice and Climate Change, Vol. 2 (Columbus, Batelle Press, 1998), pp. 327-399.

Robinson, D. K. R., and Propp, T. (2008), Multi-path mapping for alignment strategies in emerging science ad technologies, Technological Forecasting and Social Change, 75, pp. $517-538$.

Siggelkow, (2007), Persuasion with case studies, Academy of Management Journal 50: 20-24.

Simon, H.A. (1969). The Sciences of the Artificial, MIT. Press, Cambridge, MA, USA. 229 p.

Smith, A., J.-P. Voss and J. Grin. 2010. Innovation studies and sustainability transitions: The allure of the multi-level perspective and its challenges. Research Policy 39: 435-48.

Suarez, F.F., (2004), Battles for technological dominance: an integrative framework, Research Policy 33 (2004), 271-286.

Taylor, C., (2004), Modern Social Imaginaries, Duke University Press, 2004.

Van Lente, H. (1993). Promising technology: The dynamics of expectations in technological development, $\mathrm{PhD}$ Thesis, Univerity of Twente, Enschede, 1993.

Van Lente, H. and A. Rip. 1998. Expectations in technological developments: An example of prospective structures to be filled in by agency. In Getting new technologies together, 195-220. Berlin: Walter de Gruyter.

Van Lente, H. and Rip, A. (1998), Expectations in technological developments: an example of prospective structures to be filled by agency, in: C. Disco \& B. van der Meulen (Eds), Getting New Technologies Together. Studies in Making Sociotechnical Order (Berlin, De Gruyter, 1998).

Van Merkerk R.O., and Robinson D. (2006), Characterizing the Emergence of a Technological Field: Expectations, Agendas and Networks in Lab-on-a-chip Technologies, Technology Analysis and Strategic Management, 18, 2006, pp. 411-428.

Van Merkerk R.O., and Van Lente H. (2005), Tracing emerging irreversibilities in emerging technologies: the case of nanotubes, Technological Forecasting and Social Change, 72, 2005, pp. 1094-1111.

Wunenburger, J.J., (1979) L'utopie ou la crise de l'imaginaire, Editions Universitaires, 1979. 


\section{Appendix 1: References of principal data sources}

Principal books:

André JM, Baslez MF, Voyager dans l'Antiquité, Fayard, 1993

Antoni A, Jacobson A, Des anticipations de Jules Verne aux réalisations d'aujourd'hui, J de Gigord éditeur, Paris, 1950.

Baudry P, Le Rêve spatial inachevé, Editions Tallandier, 2001.

Boia L, L’Exploration imaginaire de l'Espace, Editions La Découverte, Paris, 1987.

Cyrano de Bergerac S, Histoire comique des Etats et Empire du Soleil, Edition Broché, 2002.

Durand G, Les structures anthropologiques de l'imaginaire, Editions Bordas, Paris, 1969.

Durand Y, L'exploration de l'imaginaire : Introduction à la modélisation des Univers Mythiques, Bibliothèque de l'imaginaire, L'Espace bleu, Paris, 1988.

Heidmann R, Planète Mars : Une attraction irrésistible, Alvik Editions, Paris, 2005.

Kosmodemianski A, Constantin Tsiolkovski, sa vie son œuvre, Editions en langues étrangères, Moscou, 1957.

Newton I, Principes Mathématiques de la Philosophie Naturelle, Edition Jacques Gabay, Paris, 1990.

Pacey A, The Maze of Ingenuity : Ideas and Idealism in the Development of Technology, The MIT Press, 1976.

Talbot E, CEuvres complètes de Lucien de Samosate, Tome premier, Deuxième édition, Paris librairie de L. Hachette et Cie, Nº77, Paris, 1866.

Villain J, 50 années d'ère spatiale, Toulouse, 2007.

Villain J, A la Conquêtes de l’Espace, Edition Vuibert, Paris, 2007.

Villain J, Dans les coulisses de la conquête spatiale, Editions Cépadues, Toulouse, 2003.

Villain J, L'aventure millénaire des fusées, Edition Pocket, Paris, 1993.

Von Braun W, Project Mars a Technical Tale, 1952.

Zubrin R, Cap sur Mars, Editions Goursau, Saint-Orens de Gameville, 2004.

Principal rapports:

Battrick B, Lacoste H, Warmbein B, Les nouvelles technologies dans la science fiction, Division des publications de l'ESA, 2002.

Berthet E, La conception innovante à l'appui d'une gestion collective des services écosystémiques: Etude d'un cas de mise en œuvre de Natura 2000 en plaine céréalière, mémoire de master, Université Paris Ouest Naterre La Défense, Mines ParisTech, ESCP, 2010.

Buedeler W, L’Année géophysique internationale, Organisation des Nations Unies pour l'éducation, la science et la culture, Paris, 1957.

Cliquet E, Scénarii et architectures de missions habitées vers Mars, rapport de stage, Ecole centrale, Octobre 2005.

Commission des communautés européennes, Espace : une nouvelle frontière européenne pour une Union en expansion, Plan d'action pour la mise en œuvre d'une politique spatiale européenne, Livre Blanc, Bruxelles, 2003.

Dunbar B, Hardin M, Mission to planet earth: Topeix/poseidon, NASA/CNES, Press Kit, August 1992.

Feuillerac Liliane, Mercator: L'océanographie opérationnelle dans le bon courant, dossier de presse, Cnes/CLS, 2001, (http:/ /www.aviso.oceanobs.com).

G. Drake B, Human Exploration of Mars : Design Reference Architecture 5.0, NASA/SP-2009566, July 2009.

Henry Jean Baptiste (2004), Système d'information spatiaux pour la gestion du risque d'inondation de plaine, thèse en géographie physique, Université Louis Pasteur - Strasbourg I, 2004. 
Herlem K, Les paradigmes organisationnels du secteur spatial a l'horizon 2030 : Etude de l'origine des ressources du secteur spatial, et de ses évolutions dans une vision française, mission prospective, master MTI (Université Paris Dauphine), 2013.

Libsig S, L'évolution des moteurs fusées en Europe et aux Etats-Unis pendant le XXème siècle, Université de technologie de Belfort-Montbéliard, mémoire d'étude, 2010.

Morrow Rosemary, Topex-Poseidon et la circulation des océans, publication CNRS, (http://www.cnrs.fr/publications/imagesdelaphysique/couv-PDF/imagephys98/7179.pdf).

Moulin H, La France dans l'Espace 1959-1979, Division des Publications de l'Agence spatiale européenne, 2006.

NASA, 2013 International Space Apps Challenge Mission Report, Juin 2013.

NASA, Human Exploration of Mars Design Reference Architecture 5.0, NASA/SP-2009-566, July 2009.

NASA, Report of the 90-Day Study on Human Exploration of the Moon and Mars, November 1989.

NASA, Technical Memorandum, Proceeding of the Symposium on manned planetary missions1963/1964 status, NASA TM X-53049, June 12, 1964

Penot J-P, Imaginaire et conquête spatiale, Centre national d'études spatiales, Toulouse, 1990.

Platoff A, Eyes on the Red Planet : Human Mars Mission Planning, 1952-1970, NASA/CR-2002208928, July 2001.

Puget JL, Animateur du rapport, Les sciences spatiales: Adapter la recherche française aux enjeux de l'Espace, Académie des sciences, 2010.

Roux B (dir.), Le Printemps technologique de Jules Verne : un Amiénois visionnaire, Amiens, Courrier Picard et Crédit Agricole de la Somme, 1985, 64 pages.

S. F. Portree D, Humans to Mars: Fifty Years of Mission Planning 1950-2000, NASA SP-20014521, February 2001.

Sartorius E, président du rapport de mission, Une ambition spatiale pour l'Europe, Centre d'Analyse Stratégique, $\mathrm{N}^{\circ} 42,2011$.

Segrestin B, Béjean M, Weil B, Explorer de nouveaux écosystèmes spatiaux : Enseignements des phases amont de la conception des Systèmes Orbitaux, Document de travail, Centre de Gestion Scientifique, Mines ParisTech, Juillet 2012.

Spehner N, Jules Verne, Éditeur de Marginalia, Longueuil, Canada, 2009.

The NASA History Series, Exploring the unknow, Selected Documents in the History of the US Civil Space program, Volume I : Organizing for Exploration, 1995.

Unesco, L'information à l'ère spatiale, le rôle de satellites de communication, organisation des Nations Unies pour l'éducation la science et la culture, Paris, 1968.

Zubrin R, Baker A and Gwynne O, Mars Direct: A Simple, Robust, and Cost Effective Architecture for the Space Exploration Initiative, American Institute of Aeronautics and Astronautics, AIAA-91-0328, 1991.

Principal articles:

Auque F (2012), Ecrire l'avenir de l'espace, le projet Astrium, Editions Choiseul, Géoéconomie, $\mathrm{N}^{\circ} 61,2012$, pp. 73-80.

Auque F (2012), Ecrire l'avenir de l'espace, le projet d'Astrium, Edition Choiseul, Géoéconomie, Paris, 2012, pp. 73-80.

Blom MH, Sennequier N (2000), L'espace privatisé : les transitions originales au secteur privé de l'opération de satellites, Annales des Mines, 2000.

Brachet G (2012), Les enjeux d'un développement durables des activités spatiales, Editions Choiseul, Géoéconomie, Nº1, 2012, pp. 95-106.

Brachet G (2012), Les enjeux d'un développement durables des activités spatiales, Edition Choiseul, Géoéconomie, Paris, 2012, pp. 95-1006. 
Cohen WM, Levinthal DA (1990), Absorptive Capacity: A New Perspective on Learning and Innovation. Administrative Science Quarterly 35 (1): 128-152.

Cohen, W. M., and Levinthal, D. A. (1990). "Absorptive Capacity: A New Perspective on Learning and Innovation.” Administrative Science Quaterly, 35 (1990), pp. 128-152.

Convert B, Demailly L (2012), Effets collatéraux de la création littéraire : l'exemple de la science fiction, Sociologie de l'Art, Edition L'Harmattan, 2012, pp. 111-133.

D’Escatha Y (2012), La place du CNES dans le paysage spatial international, Editions Choiseul, Géoéconomie, N61, 2012, pp. 31-38.

De Amicis E, Une visite à Jules Verne, 1895, Texte traduit par Olivier Favier, titre original: Una visita a Jules Verne, Juin 2012.

Dubost T, Exploration spatiale et imaginaire populaire américain 1957-2009, IRICE, Bulletin de l'Institut Renouvin, N³1, 2010, pp. 31-45.

Fernandez B (2001), L'Homme et le voyage, une connaissance éprouvée sous le signe de la rencontre, Working paper, Centre de Recherche sur l'Imaginaire Social et l'Education, Université Paris VIII, 2001.

Lenfle S (2011), The strategy of parallel approaches in projects with unforeseeable uncertainty: the Manhattan case in retrospect, International Journal of Project Management, vol. 29, $\mathrm{n}^{\circ} 4,2011$, pp. 359-373.

Lodsdon J (2012), La politique spatiale américaine : entre changement et continuité, Editions Choiseul, Géoéconomie, N61, 2012, pp. 49-59.

Logson J (2012), La politique spatiale américaine: entre changement et continuité, Edition Choiseul, Géoéconomie, Paris, 2012, pp. 49-59.

Pasco X (2009), Sortir de notre planète: nouvelles maturité, nouveaux risques dans l'espace?, Editions Choiseul, Géoéconomie, N50, 2009, pp. 125-132.

Pasco X (2012), Quel nouveau départ pour l'activité spatiale ?, Edition Choiseul, Géoéconomie, Paris, 2012, pp. 23-30.

Pasco X (2012), Quel nouveau départ pour l'activité spatiale, Editions Choiseul, Géoéconomie, $\mathrm{N}^{\circ} 61,2012$, pp. 23-30.

Sartorius E (2012), Une ambition spatiale pour l'Europe: Quelle vision française à l'horizon 2030 ?, Editions Choiseul, Géoéconomie, Nº1, 2012, pp. 39-48.

Tcheng H et al. (2009), Pour être créatif, mettez vous à la science fiction!, L'Express - Roularta, L'Expansion Managemet Review, 2009, pp. 107-113.

Web site:

Brian Berger, "Goals For The Next Century: To the Moon, Mars and Beyond ", Space.com, 14 juillet 2003: http://research.lifeboat.com/chafer.htm

Sénateur John Fitzgerald Kennedy, "If The Soviets Control Space - They can Control earth », Missiles and Rockets, 10 octobre 1960: http://www.jfklink.com/speeches/joint/app17_missilesandrockets.html\#jfk

Ronald Reagan: "Remarks at Edwards Air Force Base, California, on Completion of the Fourth Mission of the Space Shuttle Columbia, July 4, 1982. Online by Gerhard Peters and John T. Woolley, The American Presidency Project.

http://www.presidency.ucsb.edu/ws/?pid=42704 


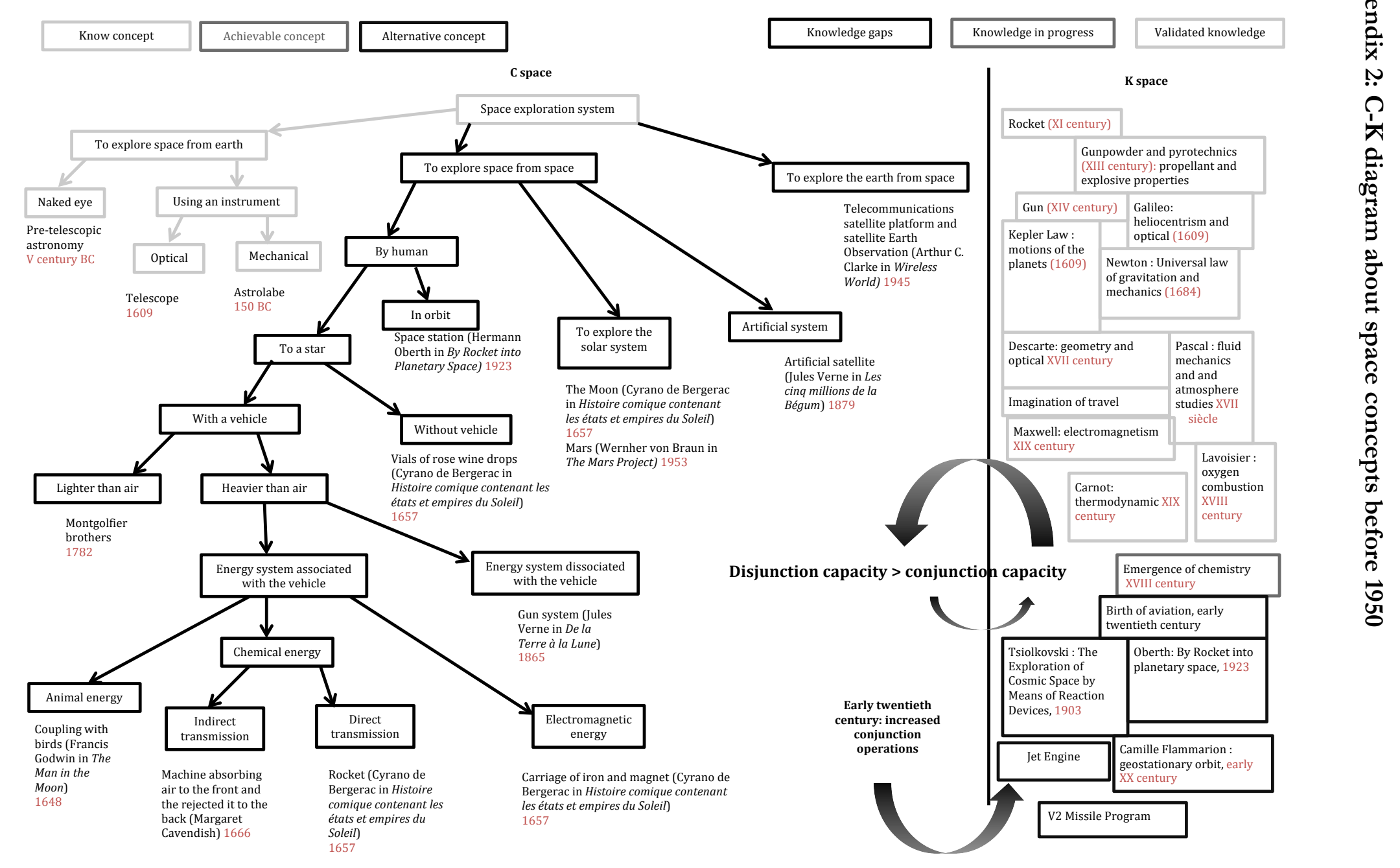


1957
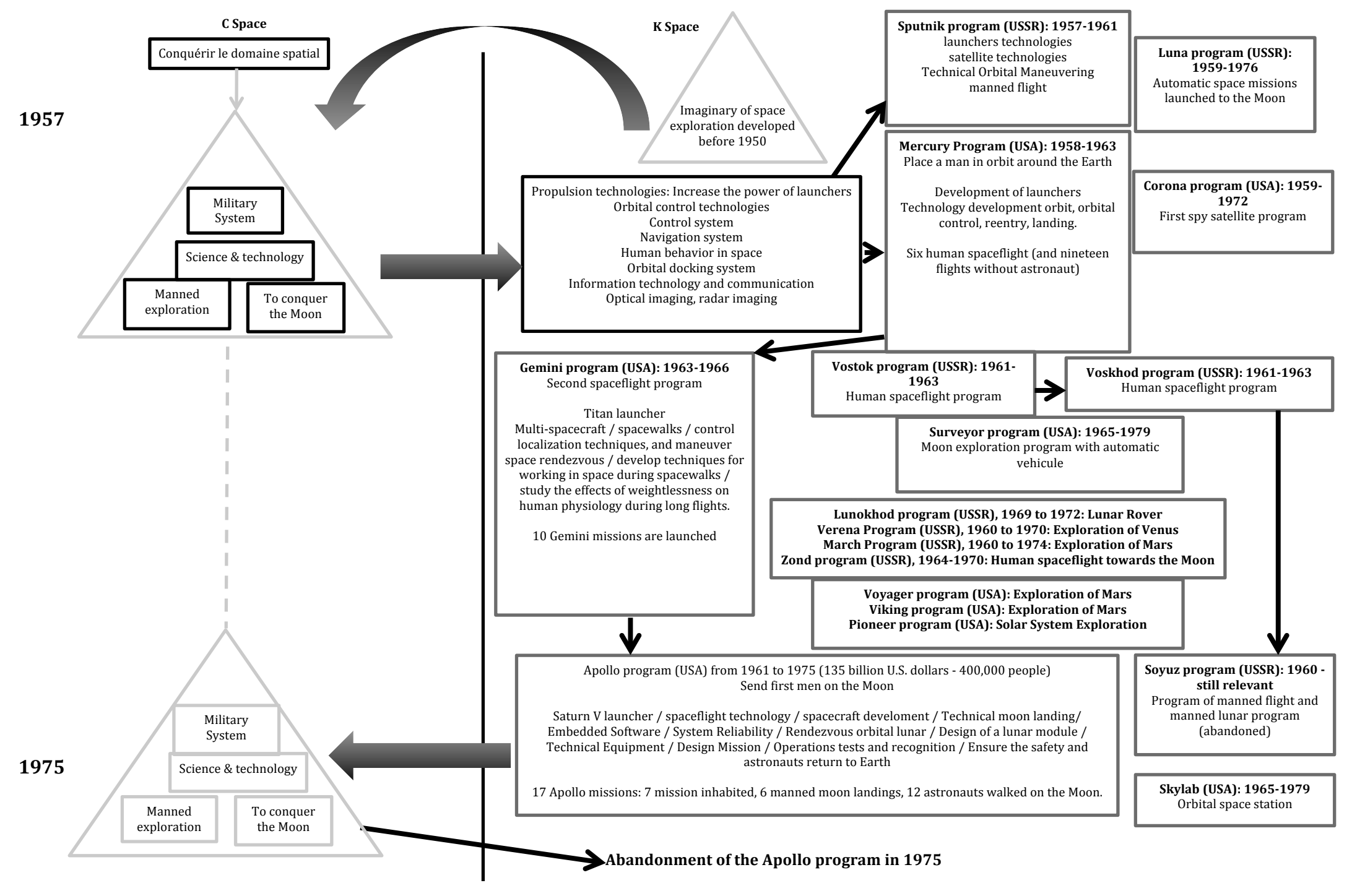
MEMORANDUM FOR

VICE PRESIDENT

In accurdance with our conversation I would like for you as Chairman of the Space Council to be in charge of making an overall survey of where we stand in space.

1. Do we have a chance of beating the Soviets by putting a laboratory in space, or by a trip around the moon, or by a rocket to land on the moon, or by a rocket to go to the moon and back with a man. Is there any other space program which promises dramatic resules in which we could win?

2. How much additional would it cost?

3. Are we working 24 hours a day on existing programs. If not, why not? If not, will you make recommendations to me as to how work can be speeded up.

4. In building large boosters should we put out emphasis on nuclear, chemical or liquid fuel. or a combination of these three?

5. Are we making maximum effort? Are we achieving necessary results?

I have asked Jim Webb. Dr. Weisner. Secretary McNamara and other responsible officials to cooperate with you fully. I would appreciate a report on this at the earliest possible moment.

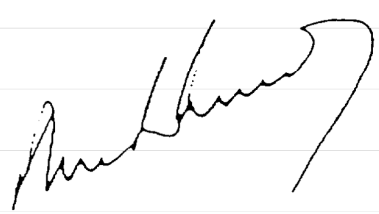




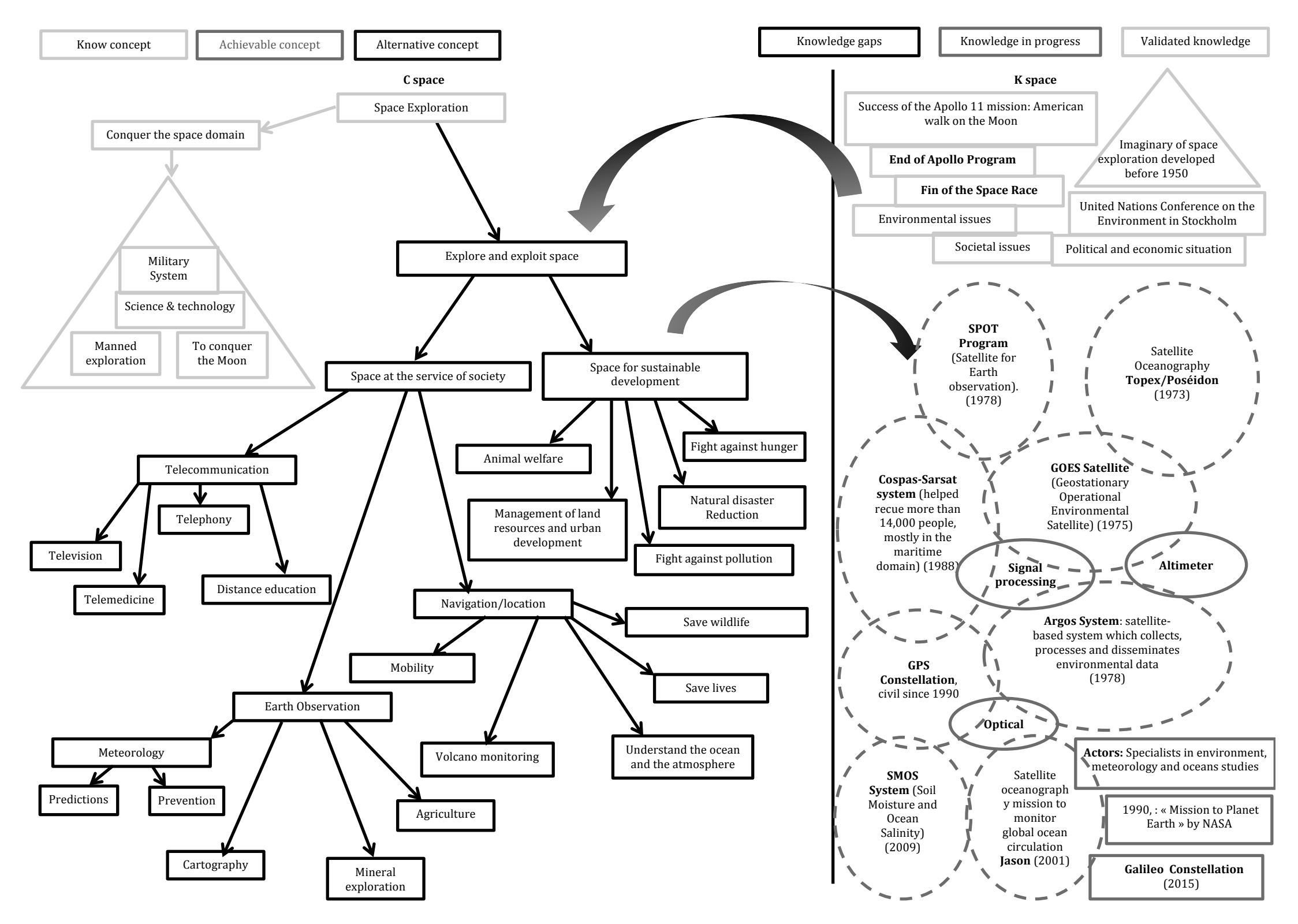

